\title{
The "Complete Package" College Library
}

BY ROBERT T. JORDAN

$F_{\mathrm{t}}^{\mathrm{s}}$ ROM ALL indications, we now have the technical capability of distributing low-cost, expendable microform copies of books (by vending machine or manually). It is probably possible to produce Kalvar or diazo (or other new process) micro-transparents or micro-opaques that could be sold at a cost of ten cents, far less than the average cost of twenty-five and one-half to fifty cents to circulate one book in a college library.

We also have the prospect that in the near future a "New Shaw" will be in existence, providing continuous, and cumulated, selection of desirable publications for college libraries, with provision for frequent revised editions of a basic retrospective list of perhaps thirty thousand titles. ${ }^{1}$

Let us project the possibilities inherent in these two potentialities, in symbiotic combination. This might introduce a complete new dimension in the mass distribution of knowledge, comparable to the mass market paperback or the LP record. Microform copies of publications included in the "New Shaw" listings (and thus indexed by the "New Shaw") would be sold or distributed from college libraries. We might term this new library service the "complete package," the possibility of providing a major library service, occupying a slight amount of space, at a fraction of the cost of conventional techniques, with the cost of circulation essentially elimi-

\footnotetext{
1 The original "Shaw", was edited by the late Charles B. Shaw, then librarian at Swarthmore. It consisted of fourteen thousand titles and was published by the ALA in 1931 as $A$ List of Books for College Libraries. The "New Shaw," as presently projected, will include twenty five thousand titles, many annotations, and symbolization for degrees of essentiality.
}

The first version of this article was included as an ancillary to an unpublished draft proposal for a "New Shaw," October 1960.

nated. Some of the possibilities such a combination offers seem worthy of discussion.

In effect, this would be an expanded version of the Harvard Classics, or Great Books of the Western World, fully indexed, each title instantly available at all times, and on the scale of a complete major college library, but at a fraction of the cost. Staff time now spent on acquisitions, processing, cataloging, and circulation (for the books represented in the complete package) could be devoted to reference and advisory service to the users, the most important of all library functions.

A frequently revised "New Shaw" with monthly cumulated supplements would take the place of the card catalog (for the books dispensed in microform) and would offer the specific advantage of scanning gained in the use of a printed catalog as compared to a card catalog. This printed basic list would be in conventional book format and could be widely available on the college campus, as well as in the library. Copies could be sold for as little as $\$ 7.00$.

The low cost per microform title would help compensate for the inherent disadvantage of its being in microform. The key, of course, would be the development of a satisfactory viewer that could be purchased by the student, or 
loaned to the student for a semester or year at a time. ${ }^{2}$

From the viewpoint of the library, the microform collection would be disposable, comparable to the revolution brought about by the introduction of the (disposable) periodical or newspaper.

From the viewpoint of the student, a collection of "core" books could be assembled at a ridiculously low cost. The compact format would conform to the increasing mobility of the age in which we live. Students are the most mobile of all segments of our population, yet are most in need of personal libraries.

Whether to use micro-opaques (with two usable sides) or micro-transparents, and what size these cards should be, would depend on the resolution capacity and the comfort in use of a low-cost viewer (not more than $\$ 25$ in mass production). It would be desirable to have at least five hundred pages on each micro unit, so that in almost all instances each title would be on one or two cards.

The microforms could be dispensed from a conventional vending machine by using either a distinctive classification and Cutter number for each title, or by using the LC order number or publisher's code number. An area might be set aside on each card for use in the future for a mark sensing mechanism for use in more sophisticated information retrieval systems yet to be developed or perfected.

Schools not wanting their students to pay for the microforms could deduct a uniform amount each semester from the fees or tuition charged each student. However, the amounts involved would be so little that this would probably not

2 In the fourth annual report for the period ending June 30,1960 , for the Council on Library Resources, Verner W. Clapp anticipates both disposable copies in microform and the low-cost hand viewer: "It seemed clear to the Council that the usefulness of microtext, both to the individual reader and to the library, would be enhanced if there were available an inexpensive, portable hand reader which would free the use of microtext from the institutionalized device and make its use casiral, convenient, and even pleasurable. In that case, libraries might be able to supply inexpensive and dis: posable copies in microform, and required reading of scarce and out-of-print texts in colleges and university instruction might be assigned and be effected with inexpensive and disposable microcopies." be necessary. For example, circulation per year per student of an average of fifty books at ten cents would amount to $\$ 5.00$. To allow for browsing, a student not wishing to keep the microform overnight or longer would be allowed to return it for a refund on the date of sale. Each microform would be dated, as it was issued from the vending machine.

The disposable library idea should aid in elevating the status of the librarian by eliminating some of the fussiness of circulation that is becoming increasingly annoying, and obscures the true professional role of the librarian. Perhaps the majority of all students today stereotype a librarian as someone who sits behind a counter and checks out reserve books. The much maligned reserve book collection could be entirely eliminated. At the same time, a major handicap of all libraries, the unavailability of books in circulation, would be eliminated. The true indication of the usefulness of a collection is not the books indicated in its catalog, but the books actually available for use at any given instant. With this scheme, this availability would be 100 per cent at all times, at least as regards books in the complete package collection.

At first, publishers might be skeptical, and might be reluctant to release their list (with no royalty or minimal royalty) for distribution through the complete package. It might be well to start with some controlled demonstrations to test the hypothesis that widespread sales of quality titles in microform would result in increased sales of books in the more convenient conventional format (hard cover or paperback). More people go to concerts now than before the introduction of the L.P record. Another possibility would be initial restriction of the complete package to OP books and books in the public domain. A less desirable alternative would be provision for gradual fogging of the micro image in light so that each microform could 
have a predictable, and limited, useful life.

Faced with the mass of increasing publication, the trend toward independent study's making intensive use of the library, the chronic shortage of librarians, and the fantastic expansion in enrollment, college libraries are slipping behind, relatively speaking, in relation to the need. Frederick H. Wagman expresses a general view in the January 1961 issue of the Library Quarterly: "the most important college problems of the next decade may well relate to the establishment and maintenance of libraries at new two-year institutions that have no academic tradition." There is a striking need for some way to increase drastically the quality of college libraries, especially in 'have not' institutions, particularly for the benefit of the minority of talented students present in all colleges who desperately need access to increased library resources. (The median college library currently acquires less than half of the minimum number of titles it needs, and even then cannot offer satisfactory reference or advisory service because of the high proportion of staff time spent on technical processing.) The availability of so much superb material, and the inclusion of so many books not now available would greatly increase the confidence of faculties in libraries and would increase the use of libraries because of the much greater degree of success in search for material.

Perhaps this concept would have such compelling value that a foundation could be persuaded to underwrite the developmental cost, and subsidize the issuance of the complete package to libraries of perhaps less than twenty thousand volumes that were deserving of assistance (inadequate financial base, recency of establishment, etc.). Perhaps all other libraries could order the complete package at three-fourths the actual cost. After five years, the project would be designed to be self-supporting. Perhaps three dis- pensing machines, sufficient for a stock of thirty thousand titles, would sell for $\$ 10,000$ each, and would amortize their initial cost within ten years.

This complete package should have appeal even to very large libraries. The duplication wouldn't matter. First, the cost of the duplicated material would be low. Second, the provision for sale of the microform to students would be an appealing new concept. Third, it would be an asset to have the microforms in reserve, for use when the conventional copies in hard-cover format were in circulation. Fourth, there would not likely be a high percentage of duplication, even in large libraries, because of differences in opinion as to which books are considered most important, because of widespread failure to acquire needed books, and because of books lost and in circulation. Fifth, the complete package idea would have appeal to large institutions as an economical method of helping establish new separate lower division or undergraduate libraries, or of new branch collections on large campuses, where large proportions of the students are far distant from the main library. Sixth, the printed book catalog (the "New Shaw") would be an attraction, offering more convenient and more detailed indexing (to the microforms) than a card catalog.

However, a library should never confine itself exclusively to the complete package. It should never be used in such a way as to reduce existing services, i.e., no library should acquire the complete package and reduce its expenditures for hard-bound books. A contractual condition for the distribution of the complete package would be assurance that at all times an adequate budget and staff be maintained for additional books, chosen locally, for local needs. A library would accept the complete package as a supplement and operate it in conjunction with its own service.

Obviously, this proposal could have 
important implications in public libraries; but the first application of the complete package concept should probably come at colleges, because of the intensive use of books by students and because of superior facilities for the distribution of the hand viewer.

In summary, the complete package offers a two-fold qualitative increase in the value of the college library. First, the possibility of a dramatic increase in the number of titles available at a negligible increase in cost, staff, and space (less than the space occupied by three large "Coke" dispensers). Second, the possibility of a dramatic increase in quality because of the inclusion of a large proportion of commonly accepted "basic" titles.

\section{Notes on PAckage Libraries}

The package library concept (the careful expert centralized compilation and distribution of basic books, offering important economies in selection and acquisition expense) is almost as old as are libraries in America. The parochial libraries organized in the American colonies by the Rev. Thomas Bray, founder of the Society for the Propagation of the Gospel and the Society for Promoting Christian Knowledge, were essentially package libraries, being more or less uniform, selected boxes of books sent over from England for the enlightenment of the pioneers in a new land. ${ }^{3}$

There was much interest in stimulating the proliferation of social libraries in the last part of the eighteenth century. The Rev. Thaddeus M. Harris, librarian of Harvard, published in 1793 A Selected Catalogue of Some of the Most Esteemed Publications in the English Language Proper To Form a Social Library. Noah Webster, known for his dictionaries and predecessor of Dewey as a spelling reformer, wrote in 1790: "Another institution favorable to knowl-

\footnotetext{
${ }^{3}$ Charles Seymour Thompson. Evolution of the American Public Library, 1653-1876 (Washington: Scarecrow Press, 1952).
}

edge is the establishment of parish libraries. . . One hundred volumes of books, selected from the best writers on ethics, divinity, and history, and read by the principal inhabitants of a town or village, will have an amazing influence in spreading knowledge, correcting the morals, and softening the manners of a nation."

One of Melvil Dewey's foremost projects was the A.L.A. Catalog, which in its development became associated with the model library exhibited at the Chicago World's Fair. Dewey felt that the A. L. A. Catalog, as a well-rounded, model collection of the five thousand best books in the English language would be duplicated in many libraries. ${ }^{4}$

Many of our public library branches (and bookmobiles) are essentially package libraries, i.e. uniform, carefully selected collections made by a central agency. Package libraries for seamen and soldiers have often been developed in America, the most noteworthy example being the Armed Services Editions of paperbacks distributed by the millions in the second world war (credited with helping to convince publishers of the popularity and potentiality of paperbacks). ${ }^{5}$ There are many interesting package library projects, at the present time, in many countries of the world; within the United States, there has been, for example, the traveling high school library program of the A.A.A.S. For overseas distribution, there have been packages of books assembled by CARE's book fund, ICA, and the Carnegie Corporation (which sponsored packages of 350 books for free distribution to libraries in the British Commonwealth) ${ }^{6} \mathrm{~A}$ recent article in California Librarian and republished in Library Journal, is an eloquent plea to flood college cam-

4 Russell E. Bidlack: "The Coming Catalogue" or Melvil Dewey's Flyingmachine: Being the Historical Background of the ALA Catalog," Library Quarterly, XXVII (1957), 137-60.

5 Frank L. Schick, The Paperbound Books in America; the History of Paperbacks and Their European Background (New York: Bowker, 1958).

Eric Larrabee, ed., American Panorama (New York: New York University Press, 1957).

COLLEGE AND RESEARCH LIBRARIES 
puses with giveaway collections of paperbacks and the establishment of model "package" paperback collections in all public libraries. ${ }^{7}$

The University of Cincinnati Library has assembled a list of seven hundred paperback titles "prepared with great care by a group of the faculty" to be given away to upperclass students in the Engineering College. The program is financed by a grant from the General Electric Foundation. ${ }^{8}$

The Ford Foundation and the Council on Library Resources have both been interested in exploring the potentialities of package libraries to meet the critical needs of colleges faced with rapid expansion in the period ahead; CLR has taken no action up to now because of a lack of a suitable device to permit individual private use of microforms, the copyright problem, and the lack of an up-to-date list. In a memorandum to Richard B. Harwell, Mr. Clapp, president of CLR, expressed interest in exploring the potentialities of package Iibraries and in determining whether a basic collection in microform would serve the purposes that are required of basic collections. ${ }^{9}$

\section{Notes on Low-Cost Microfilm Copies OF BOOKs}

(The disposable, dispensing, reproducing, duplicating, or slot machine library).

The idea of mass distribution of lowcost, expendable microform copies of books (either by slot machine or manually) is rather new; perhaps the first person to advance this concept was Fremont Rider, who wrote (in 1944) of the possibility of college and research libraries providing expendable copies of material on microform either in the origi-

7 William Emerson Hinchliff, "Two Proposals for Bold Use of Paperbound Books in California's Colleges, Schools, and Public Libraries," California Librarian XXII (1961), 63-69 (an abbreviated version of this article appears in the September 15, 1961 issue of Library Journal).

8 "A Program of Guided Reading," Library Journal LXXXVI (1961), 1839-40

Verner, W. Clapp, "Package College Libraries in Microform" (Memorandum to Richard B. Harwell, March 17, 1960) mimeographed. nal size or as microcopies to be distributed through slot machines. ${ }^{10}$ E. E. Williams advanced a similar idea. ${ }^{11}$ The last few pages of Ralph Shaw's long article in Libri in 1958 offer a proposal for a package library based on the Lamont list (or similar lists) to be distributed at $60 \mathrm{di}$ ameter reduction on $35 \mathrm{~mm}$ microfilm strips, access to be by use of edge notching, and total cost of each package estimated at $\$ 8,000$ to $\$ 10,000$. However, Shaw did not include any suggestion for making disposable copies for distribution to students. ${ }^{12}$ Peter Scott, in Library Trends in 1960, advocated recognition of three complete systems for use of microforms: for reduction of storage space, "to provide copies quickly and economically on request in lieu of a loan," and as a method of original publication. ${ }^{13}$ In the same issue of Library Trends, Lawrence E. Thompson advocated distribution of disposable microcopies by airmail or, even better, some form of wirephoto transmission from major depositories, rather than having libraries "compelled to buy whole sets of microfacsimile editions so that an occasional reproduction can be made on the spot." 14 L. B. Heilprin, in an address to the annual meeting of the National Microfilm Association in Chicago, April 4-6, 1961, suggested there were two major types of libraries, the circulating library and the duplicating library, the latter to make microcopies on individual order from a master file of negatives. ${ }^{15,} 16$

An increasing number of special libraries are already essentially dispensing

(Continued on page 421)

10 Fremont Rider, The Scholar and the Future of the Research Library (Hadham, 1944).

11 E. E. Williams, "Microbibliography; a Possible Alternative to Microcards," ALA Bulletin, XXXIX (1945), 450-54.

12 Ralph Shaw “Mechanical Storage Handling, Retrieval, and Supply of Information," Libri, VIII (1958), 1-48.

${ }_{13}$ Peter Scott, "Advances and Goals in Microphotog. raphy," Library Trends, VIII (1960), 458-92.

14 Lawrence S. Thompson. "Microforms as Library Resources," Library Trends, VIII (1960), 359-71.

${ }^{15}$ L. B. Heilprin, "Communication Engineering Ap. proach to Microforms," American Documentation, XII $(1961), 213-18$.

${ }_{16} \mathrm{~L}$. B. Heilprin, "An Economic Model of a Duplicating Library" (paper in progress). 
Olympic Blvd., Los Angeles 15. v. 1, no. 1, Feb. 1962. Monthly. $\$ 6.00$.

Sound-Its Uses and Control. Subscription Dept., 335 E. 45th St., New York 17. v. 1, no. 1, Jan.Feb. 1962. Bimonthly. $\$ 8.00$.

Stomatologic Titles. School of Dentistry, West Virginia University, Morgantown. no. 1, Oct. 1961. Irregular. Price not given.

Storia e Politica. Casa Editrice Dott. A. Guiffrè, via Solferino 19, Milan, Italy. v. 1, no. 1, Jan. 1962. Quarterly. $l 4000$.

Sludies in Elhnomusicology. Oak Publications, Inc., 121 W. 47th St., New York 36. v. I, 1961. Frequency not given. $\$ 2.50$ per issue.

Studies in Romanticism. 236 Bay State Rd., Boston 15. v. 1, no. 1, Autumn 1961. Quarterly. $\$ 4.00$

Television Quarterly. National Academy of Television Arts and Sciences, 54 W. 40th St., New York 18. v. 1, no. 1, Feb. 1962. Quarterly. $\$ 5.00$.

This Month. Gilberton Co., Inc., 101 Fifth Ave., New York. Feb. 1962. Monthly. 35 $\not$ per issue.

Topic. Subscription Manager, 6-9 Charterhouse Sq., London EC1, England. v. 1, no. 1, 21 Oct. 1961. Weekly. $£^{5} 18 s 0 d$.

Traffic Management. Watson Publications, Inc.,
201 N. Wells St., Chicago 6. v. 1, no. I, Jan. 1962. Monthly. $\$ 10.00$.

USA $\boldsymbol{I}$. USA 1, Inc., 310 E. 44th St., New York 17. v. 1, no. 1, Apr. 1962. Monthly. \$15.00.

Union Review. 1600 Holloway Ave., San Francisco. v. 1, no. 1, 1962. Quarterly. \$3.50.

University Woman. Fairleigh Dickinson University, 285 Madison Ave., Madison, N.J. v. 1, no. 1, 1962. Quarterly. \$4.00.

W. K. Wallace Confidential. American Institute of Tax Practice, 444 Madison Ave., New York 22. v. 1, no. 1, Jan. 15, 1962. Semimonthly. $\$ 36.00$.

Women's Education. American Association of University Women Educational Foundation, 2401 Virginia Ave. N.W., Washington 7, D.C. v. 1, no. 1, Mar. 1962. Frequency not given. $\$ 2.00$.

The Yuva Newsletter. Central Asian Research Centre, 66 King's Rd., London SW3, England. v. 1, no. 1, Jan. 1962. Quarterly. 7/6.

Zimbabgwe Review. External Affairs Mission, Southern Rhodesia National Democratic Party, 5 Ahmed Hishmat St., Zamalek, Cario. v. 1, [no. 1] Aug. 1961. Frequency not given. Price not given.

\section{"Complete Package"...}

(Continued from page 409)

or reproducing in their type of operation, lending very little, if any, of their collection, but dispensing microform and enlarged paper copies. Examples are the collection of engineering drawings at the Bell Telephone Laboratories at Murray Hill, N. J., and the medical journals and reports at Merck, Sharp, and Dohme. Many of the military libraries are of this type, notably that of ASTIA and the Air Force. ${ }^{17,}{ }^{18}$ Similar operations are found in a few foreign countries.

The only major large research library to give away microfilm or paper copies

${ }^{17}$ Nonconventional Technical Information Systems in Current Use, (Washington: National Science Foundation, 1958- ).

Brownson, "Research on Handling Scientific Information," Science, CXXXII (1960), 1922-31. of journal articles, rather than lending the volume, is the National Library of Medicine, which first started this practice more than twenty years ago (as the Army Medical Library). ${ }^{19}$ Many libraries provide photo duplication services. The Crerar Library plans to emphasize increasingly both storage in microform and enlarged paper copies.

In the last couple of years university libraries have found an almost unlimited market from their patrons for near print reproductions from the Xerox 914 Copier, usually at $10 \phi$ a copy. Even more recently, the user-operated "Docustat", with continuous tone capability, has made its appearance in university libraries, at $25 \phi$ a copy, or less.

19 Robert H. Muller, "Policy Questions Relating to Library Photoduplication Laboratories," Library Trends, VIII (1960), 414-31. 